\title{
Konstruksi Makna Hijrah Bagi Anggota Komunitas Let's Hijrah Dalam Media Sosial Line
}

\author{
Ditha Ditha Prasanti \\ Universitas Padjadjaran Bandung, Indonesia \\ dithaprasanti@gmail.com \\ Sri Seti Indriani \\ Universitas Padjadjaran Bandung, Indonesia \\ rahadianindri@gmail.com
}

\begin{abstract}
Abstrak
Hijrah memiliki makna yang berbeda bagi anggota komunitas Let's Hijrah. Komunitas Islam yang satu ini menamai komunitasnya Let's Hijrah sesuai dengan harapan dan tujuan hidupnya untuk mengarah pada perubahan kehidupan yang lebih baik. Dalam penelitian ini, penulis mengungkapkan konstruksi makna hijrah sendiri bagi anggota komunitas Let's Hijrah dalam media sosial LINE. Komunitas ini memberikan segala macam informasi dan memantau segala aktivitasnya melalui akun media sosial group LINE. Jadi, proses komunikasi yang terjalin pun lebih dominan terjadi dalam akun media sosial LINE tersebut. Metode penelitian yang digunakan dalam penelitian ini adalah metode etnografi virtual. Hasil penelitian yang telah dilakukan ini menunjukkan bahwa kontruksi makna hijrah bagi anggota komunitas Ler's Hijrah dalam media sosial LINE terdiri dari: (1) Hijrah disepakati sebagai tujuan hidup untuk melakukan perubahan menuju hal yang lebih baik sesuai dengan ajaran islam; (2) Hijrah harus ditunjukkan dalam konteks verbal maupun konteks non verbal oleh setiap anggota komunitas Let's Hijrah tersebut; (3) Hijrah juga dimaknai sebagai pembentukan identitas diri setiap anggota dalam komunitas Let's Hijrah.
\end{abstract}

\section{Kata Kunci: konstruksi makna; hijrah; media sosial; komunitas Let’s Hijrah}

\begin{abstract}
Hijrah has different meanings for members of Let's Hijrah community. This Islamic community calls its community Let's Hijrah according to its hopes and goals in life to lead to a better life change. In this study, the writer wanted to know the construction of the meaning of hijrah itself for members of Let's Hijrah community in social media LINE. This community provides all kinds of information and monitors all its activities through LINE's social media group account. Thus, the process of communication that exists was more dominant in the LINE social media accounts. This research has used the virtual ethnography's method. The author uses a qualitative approach in explaining this research. The results of this research have shown that the construction of the meaning of hijra for the members of Ler's Hijrah community in LINE social media consists of: (1) Hijrah is agreed as the purpose of life to make a change to a better thing according to the teachings of Islam; (2) Hijrah must be demonstrated in both verbal and non-verbal contexts by every member of Let's Hijrah community; (3) Hijrah is also interpreted as the formation of each member's identity in the community of Let's Hijrah.
\end{abstract}


Keywords: construction meaning; hijrah; social media; Let's Hijrah's community

\section{A. Pendahuluan}

Dalam sebuah komunitas, akan terlihat sekelompok orang yang memiliki tujuan yang sama telah berkumpul dalam kelompok tersebut. Ada beragam jenis komunitas yang dapat ditemukan di era modern ini. Apalagi saat ini komunitas tersebut pun terwadahi dengan adanya media sosial yang bervariasi. Salah satu komunitas yang unik dan menarik untuk diteliti adalah komunitas Let's Hijrah.

Fenomena tersebut juga dipertegas dengan berbagai macam pemberitaan dalam media online. Penulis juga menemukan salah satu artikel yang menceritakan maraknya anak-anak muda yang menyelami ilmu agama memberikan ketenangan rohani di Bandung. Bermunculannya para ustadz yang mampu menarik perhatian anak muda pun meramaikan nuansa rohani tersebut, mulai dari ustadz Hanan Attaki, ustadz Adi Hidayat, ustadz Abdul Somad, dan lainnya. ${ }^{1}$

Dalam artikel lain, penulis juga menemukan kajian tentang hijrah, Hair mengatakan bahwa hijrah yang secara bahasa berarti berpindah, digunakan sebagai sebutan untuk menamai sebuah gerakan yang mengajak kaum muslim, khususnya anak muda, untuk "berpindah" menjadi pribadi yang lebih baik dengan cara meningkatkan ketaatan dalam menjalankan syariat agama ${ }^{2}$. Tidak jelas siapa yang memulai gerakan ini. Sebagai sebuah fenomena, hijrah sebenarnya sudah muncul sejak lama, dimulai dari kalangan musisi seperti Gito Rollies atau Sakti 'Sheila On 7'. Meskipun perubahan yang mereka lakukan secara substansial adalah hijrah, tapi masyarakat dan media kala itu tidak pernah menyebutnya demikian. Penyebutan hijrah untuk perubahan seperti yang dilakukan para musisi di atas baru terjadi belakangan ini.

Menurut Nasrullah, media sosial adalah medium di internet yang memungkinkan pengguna merepresentasikan dirinya maupun berinteraksi, bekerja sama, berbagi, berkomunikasi dengan pengguna lain, dan membentuk ikatan sosial secara virtual ${ }^{3}$. Dalam media sosial LINE, terdapat fitur sticker yang menjadi ciri khasnya. Sticker buatan LINE inilah yang menjadi pelopor para aplikasi chatting lain untuk membuat hal serupa. Sticker LINE sendiri ada yang gratis dan ada yang berbayar. Media Sosial LINE bukan sekedar aplikasi chatting tetapi juga aplikasi sosial dalam berhubungan dengan teman dan keluarga yang interaktif serta lebih fleksibel.

1 B. Raharjo, "Fenomena Pemuda Hijrah: Demam Ilmu Agama di kota Bandung”. 2018. Retrieved from https://nasional.republika.co.id/berita/nasional/news-analysis/pismt6415/fenomenapemuda-hijrah-demam-ilmu-agama-di-kota-bandung-part1

2 Hair, A. Fenomena Hijrah di kalangan Anak Muda. 2018. Retrieved from https://news.detik.com/kolom/d-3840983/fenomena-hijrah-di-kalangan-anak-muda.

${ }^{3}$ Nasrullah, R. Media Sosial: perspektif Komunikasi, Budaya, dan Sosioteknologi. Bandung: Remaja Rosdakarya, 2015, h.11. 
Berbagai fenomena di atas menjadi nilai urgensitas tersendiri, pentingnya dilakukan penelitian ini. Terlepas dari maraknya pemberitaan dalam media yang menyoroti hijrah sebagai trend yang dilakukan artis/orang terkenal maupun fenomena lainnya. Apalagi generasi muda yang memiliki alasan tersendiri dalam melakukan "hijrah". Bermula dari kata hijrah, anak-anak muda tak ayal juga menyebutkan kata hijrah sebagai motivasi mereka dalam mengikuti berbagai kajian rohani. Hijrah memiliki makna yang berbeda bagi anggota komunitas Let's Hijrah. Komunitas Islam yang satu ini menamai komunitasnya Let's Hijrah sesuai dengan harapannya untuk mengarah pada perubahan kehidupan yang lebih baik. Dalam penelitian ini, penulis bertujuan mengungkapkan konstruksi makna hijrah sendiri bagi anggota komunitas Let's Hijrah dalam media sosial LINE. Komunitas ini memberikan segala macam informasi dan memantau segala aktivitasnya melalui akun media sosial group LINE. Jadi, proses komunikasi yang terjalin pun lebih dominan terjadi dalam akun media sosial LINE tersebut. Dalam hal ini, penulis juga melakukan penelusuran studi terdahulu tentang konsep hijrah.

Ada beberapa penelitian terdahulu yang membahas studi hijrah, tetapi dari segi substansi dan objek penelitian, tentu berbeda dengan penelitian yang dilakukan penulis. Hal ini juga menunjukkan urgensitas dan pentingnya dilakukan penelitian ini. Akhunov, Khamidov, Abrorov menjelaskan penelitiannya tentang konsep Hijrah yang diangkat yaitu muslim Rusia ${ }^{4}$. Artikel tersebut bertujuan untuk mengungkapkan dan menganalisis perkembangan baru, khusus untuk Muslim Rusia, yaitu, fenomena migrasi ke Turki untuk tempat tinggal karena keyakinan ideologis. Istilah historis "hijrah" digunakan pada masa Nabi, dan sekarang juga digunakan oleh para imigran. Berdasarkan pemantauan media massa, media sosial, wawancara individu, salah satu tren penting dari proses ini dianggap sebagai contoh-contoh dari kehidupan para imigran Muslim diberikan, pengalaman yang dikumpulkan dari kehidupan mereka di Turki digeneralisasi. Hasil yang disajikan dalam artikel ini menunjukkan pengaruh sosial, ekonomi, proses politik dan budaya, yang terjadi di Rusia modern pada ideologi dan posisi imigran masa depan. Temuan tersebut juga dapat dilakukan untuk penyelidikan migrasi masalah dan diskusi sosial modern tentang tempat agama di negara sekuler. Baru-baru ini konsep "Hijrah" telah mendapat suara dan konten yang berbeda. Muslim Hijrah modern dipahami sebagai relokasi orang-orang dari negaranegara non-Muslim untuk mengikuti prinsip-prinsip Islam dalam kehidupan seharihari mereka.Terutama ini berlaku untuk Muslim dari Federasi Rusia dan beberapa mantan republik Uni Soviet yang memahami Hijrah sejauh pindah ke Turki dan negara lainnya.

Betapa pentingnya bahasan tentang hijrah, hal ini menunjukkan adanya urgensitas tentang konsep hijrah tersebut. Bahkan penulis juga menemukan salah satu disertasi yang mengangkat tentang konsep hijrah. Shawkat menyampaikan bahwa tujuan penelitiannya adalah untuk dapat membedakan berbagai titik fokus yang terdiri

\footnotetext{
${ }^{4}$ Akhunov, A. M., Khamidov, E. N., \& Abrorov, I. "Hijrah Of Russian Muslims To Turkey: Pro Et Contra". Man In India, 97(8), 2017: 205-215.
} 
dalam membangun identitas hijrah ${ }^{5}$. Penelitiannya tersebut membutuhkan studi tentang ruang yang berbeda dalam kehidupan Hijrah, seperti agama, pemerintah, media, dan kehidupan pribadi mereka. Shawkat menggunakan metode interpretivisme, dalam wawancara terstruktur yang terbuka dengan peserta. Temuan tersebut menunjukkan korelasi yang pasti antara masa kecil yang traumatis dan individu yang bergabung dengan masyarakat, daripada para peserta yang dengan sengaja memilih pilihan gaya hidup. Kesenjangan dengan masyarakat arus utama semakin diperkuat karena kurangnya pendidikan.

Kedua penelitian di atas memiliki sudut pandang yang berbeda dengan penelitian yang dilakukan penulis. Akhunov dkk mengangkat konsep hijrah dari muslim yang berada di Rusia, sedangkan Shawkat menjelaskan konsep hijrah bagi muslim yang berada di Bangladesh. Bahkan, kata hijrah di Indonesia pun mulai bermunculan digunakan oleh beberapa komunitas saat ini. Ini sebagai salah satu nilai kebaruan penelitian yang dilakukan penulis. Penulis melihat adanya nilai kebaruan dalam kedua penelitian tersebut, sehingga penulis mengangkat konsep lain yaitu tentang konstruksi makna hijrah dalam komunitas Let's Hijrah yang eksis dalam media sosial LINE, dimana komunitas tersebut berada di Bandung.

Dalam penelitian sebelumnya yang telah dilakukan penulis, Prasanti \& Indriani, yang juga membahas mengenai satu grup pemuda Islam ini, komunitas ini bertujuan mengundang semua remaja agar melaksanakan hijrah ${ }^{6}$. Komunitas Let's Hijrah sendiri memiliki simbol yang diciptakan oleh ER beserta beberapa anggotanya, sebagai lambang grupnya. Peneliti membahas tentang interaksi sosial yang terjadi antar sesama anggota di dalam grup LINE Let's Hijrah, topik yang mereka bicarakan, serta efek yang timbul dalam kehidupan mereka sehari-hari dari anggota grup tersebut. Komunikasi merupakan aspek yang tidak dapat dipisahkan dalam kehidupan sehari-hari. Tanpa disadari, manusia melakukan interaksi satu sama lainnya untuk memenuhi kebutuhan berkomunikasi ini. Setiap individu melakukan interaksi sosial, tidak terbatas antar individu saja, tetapi bisa juga berinteraksi dalam sebuah kelompok. Maka dari itu, penelitian sebelumnya ini membahas tentang "Interaksi Sosial Anggota Komunitas Let's Hijrah dalam Media Sosial Group LINE".

Penelitian yang menfokuskan pada makna hijrah dan penggunaan media sosial telah banyak dilakukan. Penelitian yang menfokuskan pada makna hijrah sebagaimana dilakukan oleh Setiawan, Desiana, Wulandari, dan Salsabila pada mahasiswa Fikom Unisba lewat Komunitas ('followers') Akun 'LINE@DakwahIslam'. Penelitian ini menemukan bahwa mahasiswa Fakultas Ilmu

5 Shawkat, S. S. "Construction of the Hijra identity". Doctoral dissertation, BRAC University.. BRAC University, 2016.

6 Prasanti, Ditha; Indriani, S. "Interaksi Sosial Anggota Komunitas Let's Hijrah Dalam Media Sosial Group Line”. The Messenger, 9(2), (2017): 143-152.

7 Erik Setiawan, Fauziah Ismi Desiana, Widi Wulandari, Indah Salsabila. "Makna Hijrah pada Mahasiswa Fikom Unisba di Komunitas ('followers') Akun 'LINE@DakwahIslam'”. MediaTor, Vol 10 (1), (Juni 2017): 97-108 
Komunikasi Unisba, khususnya fakultas umum berusaha istiqamah dalam proses berhijrah namun teap fleksibel dan "melek" teknologi. Justru melalui kemajuan konvergensi media-lah yang menjadi awal rasa ingin tahu dan mengamalkan gaya hidup islami melalui hijrah. Demikian pula penelitian Afifah yang mengkaji bagaimana wacana media menarik perhatian dan mengkonstruk pemahamanpemahaman perempuan tentang pakaian syar'i dengan menggunakan pendekatan analisis wacana Ernesto Laclau dan Chantal Mouffe ${ }^{8}$. Riset yang khusus menganalisis pada sosok da'i yang menggunakan media social sebagai media dakwah sebagaimana dilakukan oleh Fatoni \& Rais yang meneliti tentang pengelolaan kesan dakwah oleh Ustadz Handy Bonny yang berhasil menciptakan citra yang baik lewat media social dan juga tampilan performance yang sangat mudah bisa diterima anak muda ${ }^{9}$. Penelitian lain pad sosok da'i dilakukan oleh Abdullah pada konten dakwah Hanan Attaki di media social, khususnya konten youtube bertema "Allah Kangen Hamba-Nya" yang dipublikasikan pada 06 Desember $2017^{10}$. Penelitian ini menemukan bahwa konten video "Kangen" Hanan Attaki mendapatkan respon postitif dari netizen, khususnya di kalangan anak muda dengan tingkat popularitas cukup tinggi (share, like, comment) yang mampu membangun persepsi publik, khususnya generasi milenial, tentang Tuhan dengan cara sederhana. Penelitian yang menfokuskan pada dakwah lewat media social pada komunitas tertentu dilakukan Fadilah \& Hasbiansyah tentang The Shift gerakan Pemuda Hijrah yang menemukan bahwa mayoritas gerakan ini berbasis di media sosial $^{11}$. Makna komunitas ini bagi para anggotanya adalah sebagai wasilah atau wadah untuk mempelajari dan mendalami ilmu agama. Penelitian lain dilakukan Choliq yang menfokuskan secara umum pada dakwah dengan menggunakan media social Facebook yang ternyata mendapatkan respon positif dari penggemar dalam bentuk menyukai, memberi komentar, setuju dan berusaha berkomunikasi tanpa menyanggah dan berdebat. $^{12}$

Bagaimanapun penelitian ini menfokuskan pada satu komunitas anak muda yang aktif di media social, yaitu Komunitas Let's Hijrah yang berupaya membangun makna hijrah lewat media sosial Line. Bagi anggota komunitas ini, Hijrah tidak hanya

\footnotetext{
${ }^{8}$ Nurul Afifah, "Pakaian Syar'i, Media, Dan Konstruksi Kesalehan Perempuan”. Sosiologi Reflektif, Vol 13, No. 1, (Oktober 2018): 51-63

${ }^{9}$ Uwes Fatoni \& Annisa Nafisah Rais, "Pengelolaan Kesan Da'i dalam Kegiatan Dakwah Pemuda Hijrah", KOMUNIKA: Jurnal Dakwah dan Komunikasi Vol. 12, No. 2, (Juli - Desember 2018): 211-222.

10 S. Dinar Annisa Abdullah, "Peran Hanan Attaki Dalam Membangun Persepsi Generasi Milenial Tentang Tuhan (Analisis Isi Atas Video "Kangen" Di Youtube)". Jurnal Ilmiah Mahasiswa Raushan Fikr, Vo. 7 No. 1 (2018)

11 Fadilah, Lucky Tyaz; Hasbiansyah, "Aktivitas Dakwah Komunitas The Shift Gerakan Pemuda Hijrah”, Prosiding Manajemen Komunikasi, Vol. 4 No. 1 (Februari 2018)

12 Abdul Choliq, "Dakwah Melalui Media Sosial Facebook", Jurnal Dakwah Tabligh Vol. 16 No. 2 (2015): 170-187.
} 
berupa jalan istiqamah yang harus ditempuh menuju jalan yang lebih baik, tetapi juga juga dimaknai sebagai pembentukan identitas diri setiap anggota itu sendiri, sehingga hijrah adalah penguatan dan penegasan identitas bagi mereka.

Penelitian ini menggunakan pendekatan kualitatif dengan metode etnografi virtual. Dalam penelitian ini, penulis akan menggunakan teori interaksi simbolik dalam mengkaji makna simbol dalam mengidentifikasi dirinya. Pengalaman individu dalam memahami makna Hijrah serta bagaimana simbol tersebut tertanam dalam identitas diri anggota komunitas Let's Hijrah. Penelitian kualitatif lebih ditujukan untuk mencapai pemahaman mendalam mengenai organisasi atau peristiwa khusus daripada mendeskripsikan bagian permukaan dari sampel besar dari sebuah populasi ${ }^{13}$. Studi etnografi virtual merupakan metode etnografi yang dilakukan untuk melihat fenomena sosial dan kultur pengguna di ruang siber. Sebagai sebuah kultur dan artefak kultural, cyberspace atau dunia siber bagi peneliti etnografi virtual bisa mendekati beberapa objek atau fenomena yang ada di internet ${ }^{14}$ Dalam penelitian ini, sampel ditentukan sebanyak tga orang dengan teknik sampling purposive. Teknik ini digunakan dengan cara mengambil informan sesuai dengan kriteria penelitian penulis.

\section{B. Eksistensi Komunitas Let'sh Hijrah}

Dalam penelitian ini, penulis mengangkat sebuah group media sosial yang bertemakan Islam, yaitu komunitas let's hijrah. Apabila media sosial ini digunakan dengan baik, akan memberikan banyak manfaat baik untuk setiap anggota-anggota yang tergabung, maupun bagi pemimpinnya. Pemimpin komunitas tersebut dengan mudah dapat mensyiarkan Islam, baik melalui foto maupun tulisan.

Kajian tentang komunitas dilakukan oleh beberapa peneliti lainnya, salah satunya adalah Hollenbeck \& Zinkhan yang mengangkat anti brand communities $^{15}$. Dalam artikel tersebut, mereka menggunakan metode studi kasus untuk menyelidiki proses pembelajaran yang digunakan untuk menegosiasikan makna merek dalam anti brand communities. Negosiasi makna merek adalah proses sosial di mana anggota masyarakat terlibat dalam wacana, interpretasi, dan pembuatan perasaan terkait merek. Terletak dalam teori gerakan sosial baru, kami menyelidiki komunitas antiWal-Mart. Studi kami mengidentifikasi tiga proses pembelajaran yang mendasar bagi pembentukan dan mobilisasi gerakan sosial: (1) pemikiran kontrafaktual, (2) bercerita diskursif, dan (3) observasi non-wajib.

Komunitas yang menjadi subjek penelitian ini adalah komunitas yang memiliki group online melalui media sosial LINE yang dinamakan Let's Hijrah. Let's Hijrah didirikan pertama kali oleh seorang pemuda bernama ER yang berumur 17

13 Denzin \& Lincoln. Handbook of Qualitative Research. Thousan Oaks London: Sage Publication, 1994

${ }^{14}$ Nasrullah...

15 Hollenbeck, C. R., \& Zinkhan, G. M. “Anti-Brand Communities, Negotiation Of Brand Meaning, And The Learning Process: The Case Of Wal-Mart". Consumption, Markets and Culture, 13(3) (2010), 325-345. 
tahun. Ia membangun komunitas tersebut pada bulan Februari 2017 dan hingga bulan April 2017 dan telah memiliki 200 anggota.

Komunitas ini bertujuan mengundang semua remaja agar melaksanakan hijrah. Hijrah dalam pengertian ER merupakan sebuah perubahan diri menjadi lebih baik dari sebelumnya berdasarkan ajaran Islam, menjadi khalifah dunia yang diinginkan oleh Allah SWT, sesuai dengan apa yang sudah tertulis dalam Al-Qur'an dan hadist. Komunitas Let's Hijrah itu sendiri memiliki simbol yang diciptakan oleh ER berserta beberapa kawannya, sebagai lambang grupnya.

Dalam hal lain, penulis melihat pentingnya kajian tentang konsep hijrah, ternyata konsep ini tidak hanya menarik dibahas di Indonesia, tetapi juga ada peneliti dari beberapa negara lain, contohnya peneliti yang membahas tentang komunitas Hijrah di negara India. Berbeda halnya dengan penelitian penulis, dalam penelitian tersebut memfokuskan kepada keberadaan komunitas Hijrah yang unik, berada di India. Artikel tersebut mengeksplorasi komunitas Hijrah, mencoba memahami apa artinya mengambil peran Hijrah, dan menjelaskan proses yang terlibat dalam komunitas Hijrah. Ini didasarkan pada studi etnografi Hijrah yang tinggal di New Delhi, Inda. Komunitas Hijrah selalu berada di pinggiran masyarakat, berdiam dalam kemiskinan dan dikeluarkan dari proses normalisasi. Menjadi korban dari berbagai bentuk prasangka dan intoleransi, komunitas Hijrah pun hidup dalam ketakutan dan pengasingan, seringkali di lokasi-lokasi rahasia, di Ghetto. Masalah yang dihadapi oleh kelompok-kelompok orang ini belum dieksplorasi secara memadai, terutama sebagai akibat dari sifat tersembunyi dari komunitas. Dengan membahas praktikpraktik eksklusif, artikel ini menggambarkan persimpangan antara politik identitas dan reproduksi perbedaan sosial yang dipicu oleh ketidaksetaraan dan ketidaksetaraan kelas, gender, dan seksualitas yang ada. ${ }^{16}$

Kontruksi makna hijrah bagi anggota komunitas Let's Hijrah dalam media sosial LINE terdiri atas tiga hal, pertama, Hijrah disepakati sebagai tujuan hidup untuk melakukan perubahan menuju hal yang lebih baik sesuai dengan ajaran islam; kedua, Hijrah harus ditunjukkan dalam konteks verbal maupun konteks non verbal oleh setiap anggota komunitas Let's Hijrah tersebut; dan ketiga Hijrah juga dimaknai sebagai pembentukan identitas diri setiap anggota dalam komunitas Let's Hijrah,

\section{B.1 Hijrah sebagai Tujuan Hidup}

ER, pendiri komunitas Let's Hijrah ini menyampaikan pernyataannya tentang konsep hijrah bahwa hijrah disepakati sebagai tujuan hidup untuk melakukan perubahan menuju hal yang lebih baik sesuai dengan ajaran Islam. Sebagaimana hal ini telah disepakati oleh ER bersama para anggotanya ketika ER akan mendirikan komunitas Let's Hijrah ini.

\footnotetext{
${ }^{16}$ Goel, I. “Hijra Communities Of Delhi”. Sexualities, 19(5-6) (2016): 535-546.
} 
"Dulu pas mau mendirikan komunitas ini, saya juga berpikir panjang artinya ya gak sembarangan juga saya asal bikin komunitas. Tapi karena dalam kelompok saya itu ada sekumpulan orang yang emang punya visi misi yang sama, akhirnya saya berinisiatif untuk bikin komunitas ini. Kenapa enggak kan biar kami jadi terwadahi, lalu kalo sudah terbentuk gini kan jadi siapapun yang punya visi misi yang sama juga bisa bergabung dengan kami. Pada mulanya, komunitas ini hanya diperuntukkan bagi beberapa orang, yang tergabung dalam kelompok kecil yang saya miliki. Tapi ternyata ada banyak peminatnya, para remaja islam yang saya temui juga memiliki harapan yang sama soal hidupnya. Awalnya saya memaknai hijrah sebagai langkah menuju perubahan ke arah yang lebih baik. Lalu saya diskusikan dengan anggota lain, ternyata kami punya tujuan yang sama, yaitu ingin berubah ke arah yang lebih baik sesuai dengan ajaran islam. Jadi, saya pun memberikan nama komunitas ini adalah Let's Hijrah, ya sesuai dengan tujuan bersama kami."

ER menegaskan bahwa sebagai pendiri komunitas Let's Hijrah, ER memberikan nama komunitasnya sesuai dengan tujuan bersama dari para anggotanya juga, yang berkeinginan melakukan perubahan menuju arah yang lebih baik lagi sesuai dengan ajaran islam. ER pun menyampaikan bahwa nama komunitas inipun terinspirasi dari tujuan hijrah yang selalu disebutkan oleh ER dan para anggotanya.

FZ, sebagai salah satu anggota yang aktif dalam komunitas Let's Hijrah inipun memberikan pernyataannya tentang makna Hijrah bagi dirinya sebagai anggota komunitas Let's Hijrah tersebut.

"Betul, makna hijrah buat kami itu adalah tujuan hidup, karena kami berkumpul dalam komunitas ini juga karena kami sama-sama punya tujuan hidup yang sama, yaitu ingin hijrah, berubah menuju arah yang lebih baik sesuai ajaran islam. Saya sepakat dengan ketua, ER, sekaligus pendiri komunitas ini. Bahkan, sekarang kami jadi merasa terwadahi karena kami punya group online di media sosial LINE ya. Jadi, ini memudahkan proses komunikasi yang ingin kami lakukan. Saya pribadi sih memaknai kata hijrah ini ya sebagai tujuan hidup, karena memang tujuan awal dibentuknya komunitas ini juga karena kesamaan tujuan kami, ingin hijrah, berubah menuju arah yang lebih baik sesuai ajaran islam."

Dalam wawancara berikutnya, FZ, sebagai anggota aktif dalam komunitas Let's Hijrah tersebut memberikan pernyataan yang sama mengenai makna Hijrah bagi komunitasnya. Menurut FZ, makna hijrah memang mencerminkan tujuan hidupnya saat ini yaitu melakukan perubahan menuju arah yang lebih baik sesuai dengan ajaran Islam. Hal tersebut dipertegas juga oleh AR, sebagaimana berikut: 
"Saya merasa senang dengan adanya komunitas ini. Pada awalnya sih, kami belum punya nama, ya sebelum didirikan oleh ER, ketua kami. Ya biasa aja kami suka ngumpul gitu terus diskusi tentang tujuan hidup, eh ternyata kami punya tujuan yang sama, ingin berubah jadi lebih baik. Kata-kata hijrah ini sering digaungkan oleh ER, ketua kami. Lalu kenapa ya nama komunitasnya gak pake kata "hijrah" aja. Akhirnya, ER pun memberikan nama "Let's Hijrah” sebagai seruan sekaligus motivasi, karena kami sepakat kalo makna hijrah buat kami ini adalah tujuan hidup. Jadi, kami juga bisa saling mengingatkan kalau di antara kami ada yang lupa atau lagi males ya, hehe...Taunya setelah dibuatkan akun media sosial group LINE-nya, wah anggota kami jadi semakin bertambah peminatnya."

Pernyataan di atas sudah menguatkan apa yang disampaikan oleh ER, sebagai pendiri komunitas Let's Hijrah ini. Penulis pun dapat melihat bahwa makna hijrah bagi anggota komunitas Let's Hijrah tersebut disepakati sebagai tujuan hidup, yaitu untuk melakukan perubahan menuju arah yang lebih baik sesuai ajaran Islam.

\section{B.2 Hijrah Ditunjukkan dalam Konteks Verbal maupun Nonverbal}

Berdasarkan hasil wawancara yang telah dilakukan, penulis juga melihat adanya makna lain yang terungkap dari komunitas Let's Hijrah tentang makna hijrah bagi dirinya. Makna hijrah ini juga dikatakan harus ditunjukkan dalam konteks verbal maupun konteks nonverbal oleh setiap anggota komunitas Let's Hijrah tersebut.

Menurut ER, sebagai pendiri komunitas ini, makna hijrah yang berarti tujuan hidup menuju perubahan yang lebih baik ini harus ditunjukkan dalam ucapan dan perbuatan. Artinya, ER menegaskan bahwa makna hijrah dalam komunitas Let's Hijrah tersebut diwujudkan tidak hanya dalam konteks ucapan atau pesan verbal melainkan juga dalam konteks pesan nonverbal. Konteks pesan nonverbal yang dimaksud ER disini adalah makna hijrah yang terlihat dalam penampilan dan pakaian yang dikenakan oleh anggota komunitas Let's Hijrah sendiri. Berikut ini adalah penuturan ER

"Sebenarnya gak cuman kata-kata ya, makna hijrah buat kami itu ya akan terlihat jika memang kami realisasikan gitu dalam perbuatan sehari-hari. Ya gak jauh nih misalnya dalam penampilan kami, karena kami udah tau kan pakaian yang sebaiknya dikenakan bagi kaum laki-laki bagaimana, jadi ya kami menjaga penampilan juga. Kalau sunnah rasul itu menggunakan celana yang di atas mata kaki, terus janggutnya dipanjangkan, ya itu juga yang kami lakukan. Coba diperhatikan aja sama anggota kami, sebagian besar mencerminkan makna hijrah ya lewat perbuatan yang tadi ya, apa itu namanya ya...sejenis non verbal mungkin ya..." 
Dalam hasil wawancara di atas, ER menegaskan bahwa makna hijrah bagi komunitas Let's hijrah tersebut juga harus dimaknai dalam konteks verbal maupun konteks non verbal. Konteks verbal ini ditunjukkan dengan kesepakatan yang disampaikan ER dan para anggota lainnya bahwa makna hijrah sebagai tujuan hidup menuju perubahan yang lebih baik, sedangkan dalam konteks nonverbal ini ditunjukkan melalui tindakan para anggota komunitas tersebut.

Konteks nonverbal ini terlihat pada pesan artifaktual atau penampilan yang dilakukan oleh anggota komunitas Let's Hijrah tersebut.

a. Pesan artifaktual yang dimaksud adalah pakaian, misalnya celana yang digunakan itu tidak menutupi mata kaki karena merupakan bagian dari sunnah rasul.

b. Pesan artifaktual lainnya adalah janggut yang dipanjangkan bagi kaum lakilaki, yang merupakan bagian dari sunnah rasul juga. Hal inipun telah direalisasikan oleh para anggota komunitas Let's Hijrah tersebut.

c. Pesan artifaktual selanjutnya juga terlihat pada penutup kepala, sejenis kopeah yang dikenakan oleh ER, pendiri komunitas Let's Hijrah tersebut.

Hal inipun dimaknai sama oleh anggota komunitas Let's Hijrah lainnya. FZ dan ER memberikan makna yang serupa bahwa makna hijrah ini juga direalisasikan dalam bentuk ucapan verbal dan konteks non verbal. FZ juga mengakui bahwa sebagai bagian dari anggota komunitas Let's Hijrah, FZ mengenakan celana yang tidak menutup mata kaki, memanjangkan janggut, dan mengenakan kopeah ini sebagai bagian dari bentuk hijrah yang disepakati, yang merupakan bagian dari sunnah rasul.

\section{B.3 Hijrah Sebagai Pembentukan Identitas Diri}

ER menambahkan makna lain bahwa kata hijrah juga disepakati sebagai pembentukan identitas diri bagi anggota komunitas Let's Hijrah tersebut. Menurut ER, kata hijrah ini tidak sekedar tujuan hidup yang telah disepakati oleh komunitasnya. Ada makna lain dari hijrah bagi ER dan anggota lainnya dalam komunitas tersebut.

FZ dan ER juga menjelaskan bahwa makna hijrah bagi mereka adalah sebagai pembentukan identitas diri, yang menyatakan dirinya sebagai bagian dari anggota komunitas Let's Hijrah. Berikut ini adalah penuturan FZ.

"Ada makna lain yang saya rasakan ada dari kata hijrah ini, selain tujuan hidup kami, ya kata hijrah ini nunjukkin semacam identitas diri kami. Misalnya lewat pakaian atau simbol yang kami kenakan, terus kan kami punya logo nih, gambar masjid yang seolah-olah nunjukkin bahwa ini adalah identitas diri kami. Jadi, secara gak langsung, kami jadi termotivasi untuk berubah jadi lebih baik, terus kami jadi ngerasa ini adalah identitas diri gitu, saya pribadi khususnya, merasakan ini bukan sekedar tujuan hidup, tapi jadi pembentukan identitas diri, karena saya kan udah bertekad ingin berubah jadi lebih baik sesuai ajaran agama islam”. 
Pernyataan di atas mempertegas hal yang disampaikan oleh ER sebagai pendiri komunitas Let's Hijrah. Makna hijrah bagi komunitas Let's Hijrah juga dimaknai sebagai pembentukan identitas diri, yang tercermin melalui artifaktual atau penampilan yang dikenakan para anggota komunitas Let's Hijrah tersebut. Ini menegaskan juga adanya konteks pesan nonverbal yang dilakukan para anggota komunitas tersebut.

\section{Hijrah dalam Teori Interaksi Simbolik}

Dalam bagian ini, penulis ingin memaparkan tentang relevansinya teori interaksi simbolik dengan hasil penelitian penulis. Penulis menemukan adanya asumsi interaksi simbolik yang mengangkat konsep mind, self, dan society, terdapat dalam hasil penelitian ini.

Misalnya saja, Yang, Yeh, dan Wong yang memaparkan analisis teori konstruksi sosial dalam komunitas pembelajaran online ${ }^{17}$. Seperti yang diusulkan oleh para ahli teori konstruktif sosial, pembelajaran yang bermakna dan pengembangan individu dicapai melalui interaksi sosial. Untuk mendorong interaksi sosial di antara siswa, penelitian ini membentuk komunitas pembelajaran online di mana mereka memainkan berbagai peran sebagai penulis, editor, dan komentator. Dalam memainkan peran yang berbeda, mereka membaca teks rekan, mengedit kesalahan rekan, mengevaluasi koreksi rekan editor dan akhirnya merekonstruksi teks mereka sendiri. Hasil penelitian ini menunjukkan bahwa berbagai peran yang mereka mainkan memungkinkan mereka memiliki kesempatan untuk melihat teks mereka sendiri dari sudut pandang orang lain. Berdasarkan perspektif ini, mereka lebih bersedia untuk memperoleh informasi dari dan menyumbangkan informasi kepada teman sebaya. Semua perolehan dan kontribusi informasi yang luas ini menghasilkan konstruksi makna teks ketika siswa aktif meningkatkan draft akhir mereka baik dalam revisi lokal (koreksi tata bahasa) dan revisi global (gaya, organisasi dan pengembangan teks) setelah menerima dan mengevaluasi umpan balik dari rekan editor. Draf akhir mereka sangat berbeda dari siswa pasif yang draf pertama dan terakhirnya hampir sama meskipun ada beberapa revisi tata bahasa. Studi tersebut menunjukkan bahwa, daripada hanya mengandalkan ujian konsep akhir siswa, ada manfaat dalam mendorong guru siswa untuk berpartisipasi aktif dalam interaksi sosial dengan membaca teks teman, mengedit kesalahan teman, dan mengevaluasi koreksi rekan editor selama teks.

Dalam observasi dan wawancara yang dilakukan, penulis menemukan adanya konstruksi makna hijrah yang menekankan pada sebuah aktivitas, sebagai bagian penting dari ciri khas komunitas Let's Hijrah tersebut. Sebagaimana diungkapkan

17

Yang, Y. F., Yeh, H. C., \& Wong, W. K. "The influence of social interaction on meaning construction in a virtual community". British Journal of Educational Technology, 41(2), (2010): 287386. 
dalam asumsi teori interaksi simbolik, hal ini relevan dengan fenomena hasil penelitian yang telah dilakukan penulis.

Teori komunikasi yang relevan digunakan dalam penelitian ini adalah teori interaksi simbolik. Esensi dari teori interaksi simbolik menekankan pada suatu aktivitas yang menjadi bagian penting dari ciri khas manusia, yaitu ketika komunikasi atau pertukaran simbol yang diberikan makna. Jika berbicara mengenai perspektif interaksi simbolik, sebenarnya berada di bawah perspektif fenomenologis atau perspektif interpretative. ${ }^{18}$

George H.Mead adalah pemikir yang sangat penting dalam sejarah interaksionisme simbolik. Interaksi simbolik didasarkan pada ide-ide mengenai diri dan hubungannya dengan masyarakat. Ada tiga tema besar yang mendasari asumsi dalam teori interaksi simbolik ${ }^{19}$. Jika dikaitkan dengan penelitian yang dilakukan penulis, ada beberapa hal yang relevan dengan asumsi teori interaksi simbolik ini, yaitu:

1. Pentingnya makna bagi perilaku manusia

Dalam penelitian ini, makna hijrah yang menjadi bagian penting dimaknai bagi perilaku anggota komunitas Let's Hijrah. Pendiri komunitas Let's Hijrah pun menyampaikan bahwa makna kata hijrah bagi mereka sudah disepakati menjadi tujuan hidup untuk melakukan perubahan menuju arah yang lebih baik sesuai ajaran agama Islam. Begitupun para anggota yang telah diwawancarai juga menyampaikan adanya makna hijrah yang berperan penting dalam pembentukan identitas diri bagi para anggota komunitas Let's Hijrah tersebut. Hal inipun ditunjukkan dengan antusiasme para anggota ketika pendiri komunitas membuat media sosial group LINE, sebagai wadah koordinasi dan informasi yang berhubungan seputar ajaran Islam dan kegiatan yang akan mereka lakukan.

2. Pentingnya konsep mengenai diri

Dalam penelitian ini, penulis melihat adanya konsep diri pendiri dan anggota komunitas Let's Hijrah yang memberikan sebuah motif penting untuk berperilaku yang terbentuk melalui media sosial LINE, sehingga menunjukkan identitas diri mereka sebagai bagian dari komunitas Let's Hijrah. Dalam hal ini, interaksi sosial yang terjalin antara anggota komunitas mayoritas terjadi melalui media sosial LINE. Pentingnya konsep mengenai diri ini yang kemudian memberikan sebuah motif penting untuk berperilaku, ditunjukkan dalam perilaku, baik konteks pesan verbal maupun konteks nonverbal, yaitu berupa pesan artifaktual dan pesan gesture (bahasa tubuh) para anggota komunitas Let's Hijrah.

3. Hubungan antara individu dan masyarakat

\footnotetext{
${ }^{18}$ Mulyana, D. Metodologi Penelitian Kualitatif. Bandung: PT Remaja Rosdakarya, 2001.

${ }^{19}$ West, T. Pengantar Teori Komunikasi Analisis dan Aplikasi. Jakarta: Salemba Humanika, 2018.
} 
Dalam penelitian ini, penulis melihat adanya hubungan antara individu dan masyarakat, yaitu ketika para anggota yang baru masuk pun dipengaruhi oleh proses budaya dan sosial. Proses budaya dan sosial ini merupakan rangkaian proses dari adanya struktur sosial yang dihasilkan melalui interaksi sosial. Hal ini ditunjukkan dengan adanya kesepakatan makna hijrah yang dikonstruksi sebagai tujuan hidup menuju perubahan yang lebih baik sesuai ajaran Islam; makna hijrah tersebut harus diimplementasikan dalam konteks verbal maupun konteks non verbal; dan makna hijrah tersebut menjadi wujud dari pembentukan identitas diri para anggota komunitas Let's Hijrah. Penulis melihat adanya struktur sosial yang dihasilkan melalui interaksi sosial, khususnya melalui media sosial LINE, karena dalam hal ini, makna hijrah sendiri pun dikonstruksi berdasarkan interaksi sosial yang terjalin antar anggota dan pendiri komunitas Let's Hijrah tersebut.

\section{Penutup}

Makna hijrah bagi anggota komunitas hijrah ditunagkan lewat media social LINE dipahami dalam tiga konstruksi makna, yaitu:

Pertama, Hijrah disepakati sebagai tujuan hidup untuk melakukan perubahan menuju hal yang lebih baik sesuai dengan ajaran Islam; kedua, Hijrah harus ditunjukkan dalam konteks verbal maupun konteks non verbal oleh setiap anggota komunitas Let's Hijrah tersebut; dan ketiga Hijrah juga dimaknai sebagai pembentukan identitas diri setiap anggota dalam komunitas Let's Hijrah.

\section{DAFTAR PUSTAKA}

Abdullah, Dinar Annisa, "Peran Hanan Attaki Dalam Membangun Persepsi Generasi Milenial Tentang Tuhan (Analisis Isi Atas Video "Kangen" Di Youtube)". Jurnal Ilmiah Mahasiswa Raushan Fikr, Vo. 7 No. 1 (2018)

Afifah, Nurul, "Pakaian Syar'i, Media, Dan Konstruksi Kesalehan Perempuan". Sosiologi Reflektif, Vol 13, No. 1, (Oktober 2018): 51-63

Akhunov, A. M., Khamidov, E. N., \& Abrorov, I. Hijrah Of Russian Muslims To Turkey: Pro Et Contra. Man In India, 97(8), (2017): 205-215.

Choliq, Abdul "Dakwah Melalui Media Sosial Facebook", Jurnal Dakwah Tabligh Vol. 16 No. 2 (2015): 170-187.

Fadilah, Lucky Tyaz; Hasbiansyah, "Aktivitas Dakwah Komunitas The Shift Gerakan Pemuda Hijrah”, Prosiding Manajemen Komunikasi, Vol. 4 No. 1 (Februari 2018) 
Fatoni, Uwes \& Annisa Nafisah Rais, "Pengelolaan Kesan Da'i dalam Kegiatan Dakwah Pemuda Hijrah", KOMUNIKA: Jurnal Dakwah dan Komunikasi Vol. 12, No. 2, (Juli - Desember 2018): 211-222.

Goel, I. Hijra Communities of Delhi. Sexualities, 19(5-6) (2016): 535-546.

Hair, A. "Fenomena Hijrah di kalangan Anak Muda". 2018. Retrieved from https://news.detik.com/kolom/d-3840983/fenomena-hijrah-di-kalangan-anakmuda

Hollenbeck, C. R., \& Zinkhan, G. M. "Anti-Brand Communities, Negotiation Of Brand Meaning, And The Learning Process: The Case Of Wal-Mart". Consumption, Markets and Culture, 13(3) (2010): 325-345.

Mulyana, D. Metodologi Penelitian Kualitatif. Bandung: PT Remaja Rosdakarya, 2001.

Nasrullah, R. Media Sosial: Perspektif Komunikasi, Budaya, dan Sosioteknologi. Bandung: Remaja Rosdakarya, 2015.

Prasanti, Ditha; Indriani, S. Interaksi Sosial Anggota Komunitas Let's Hijrah Dalam Media Sosial Group Line. The Messenger, 9(2), (2017): 143-152.

Raharjo, B. "Fenomena Pemuda Hijrah: Demam Ilmu Agama di kota Bandung". 2018. Retrieved from https://nasional.republika.co.id/berita/nasional/newsanalysis/pismt6415/fenomena-pemuda-hijrah-demam-ilmu-agama-di-kotabandung-part1

Setiawan, Erik, Fauziah Ismi Desiana, Widi Wulandari, Indah Salsabila. "Makna Hijrah pada Mahasiswa Fikom Unisba di Komunitas ('followers') Akun 'LINE@DakwahIslam'”. MediaTor, Vol 10 (1), (Juni 2017): 97-108

Shawkat, S. S. "Construction of the Hijra Identity". Doctoral Dissertation, BRAC University). BRAC University, 2016.

West, T. Pengantar Teori Komunikasi Analisis dan Aplikasi. Jakarta: Salemba Humanika, 2008.

Yang, Y. F., Yeh, H. C., \& Wong, W. K. The influence of social interaction on meaning construction in a virtual community. British Journal of Educational Technology, 41(2) (2010): 287-386. 